\footnotetext{
${ }^{1}$ Research Institute for the Biology of Farm Animals, Dummerstorf, Germany

${ }^{2}$ Zoological Institute and Museum, Ernst-Moritz-Arndt University, Greifswald, Germany

${ }^{3}$ Biozentrum Grindel, University Hamburg, Hamburg, Germany
}

\author{
MARCUS MAU ${ }^{1}$, CHRISTIAN MÜLLER ${ }^{2}$, JAN LANGBEIN ${ }^{1}$, CHARLOTTE REHFELDT ${ }^{1}$, \\ JAN-PETER HILDEBRANDT ${ }^{2}$ and THOMAS M. KAISER ${ }^{3}$
}

\title{
Adhesion of bovine and goat salivary proteins to dental enamel and silicate (short communication)
}

\begin{abstract}
Salivary proteins may help to prevent enamel abrasion and adverse chemical effects on teeth of herbivorous mammals. To detect potential candidates for protecting proteins, bovine and goat whole saliva were incubated with dental enamel and glass powder. Salivary proteins, bound to dental enamel and glass, were analysed by SDS-PAGE. Two distinct salivary proteins were found to adhere to bovine enamel and were identified by MS/MS mass spectrometry and protein sequencing. Both the bovine odorant-binding protein (bOBP) and the carbonic anhydrase VI (CA-VI) were components of the protein layers. The bovine CA-VI adherent to teeth may serve as a pH-regulator to protect bovine enamel from bacterial acids. The bOBP may bind odorant particles right in the oral cavity and enhance their transmission to the vomeronasal organ (VNO), the signals of which are important determinants in sexual behaviour of mammals. Another protein from bovine and goat saliva seemed to preferentially bind to glass beads. These results suggest that salivary proteins may support olfaction and protect teeth of ruminants from mechanical and chemical destruction.
\end{abstract}

Key Words: saliva, carbonic anhydrase VI (CA-VI), odorant-binding protein (OBP), enamel, vomeronasal organ (VNO)

\section{Zusammenfassung}

Titel der Arbeit: Bindung von Speichelproteinen des Rindes und der Ziege an Zahnschmelz und Silikat (Kurzmitteilung)

Speichelproteine könnten helfen, die Abnutzung des Zahnschmelzes sowie ungünstige chemische Einflüsse auf die Zähne pflanzenfressender Säugetiere zu verhindern. Um potentielle Kandidaten für schützende Proteine zu finden, wurden Rinder- und Ziegengesamtspeichel mit Schmelz- und Glaspulver inkubiert. Die am Zahnschmelz und Glas gebundenen Speichelproteine wurden daraufhin in der SDS-Gelelektrophorese analysiert. Zwei vom Rinderzahnschmelz isolierte Proteine konnten mit Hilfe der MS/MS Massenspektrometrie sowie der Proteinsequenzierung identifiziert werden. Sowohl das geruchsstoffbindende Protein (bOBP) des Rindes als auch die Carboanhydrase VI (CA-VI) waren Bestandteil der Proteinfilme. Die an den Zähnen gebundene bovine CA-VI könnte als pH-Wert-Regulator dienen, um den Zahnschmelz des Rindes vor bakteriellen Säuren zu schützen. Das bOBP könnte Geruchsstoffe direkt in der Mundhöhle binden und deren Transport zum Organon vomeronasale (VNO) verbessern, dessen Signale wichtige Faktoren im Sexualverhalten der Säugetiere sind. Ein weiteres Protein aus dem Rinder- und Ziegenspeichel zeigte anscheinend ein stärkeres Bindungsverhalten an Glas. Diese Ergebnisse lassen eine Beteiligung der Speichelproteine am Geruchssinn sowie beim Schutz der Wiederkäuerzähne vor mechanischer und chemischer Zerstörung vermuten.

Schlüsselwörter: Speichel, Carboanhydrase VI (CA-VI), geruchsstoffbindendes Protein (OBP), Zahnschmelz, Vomeronasalorgan (VNO)

\section{Introduction}

Research on the interactions between salivary proteins and dental tissues is vital primarily for dentists, but also for evolutionists and ecologists working on farm and wild animals. Although, the oral cavern is the primary interface between animals and their environment little is known about the complex connections between saliva, teeth 
and feeding adaptation. Salivary proteins might be involved in tooth protection against abrasives, in food digestion and fermentation and may have accessory functions in odorant recognition. The interaction between salivary proteins and teeth may provide first protection against abrasive food particles such as phytoliths. On the other hand, those interactions may be fundamental for digestive processes in both farm animals and wildlife.

Grasses and sedges as primary food plants of farm animals may heavily impregnate their vegetative and reproductive organs with solid particles of opaline (amorphic) silicium-dioxide $\left(\mathrm{SiO}_{2}\right)$, so-called phytoliths. Besides lignification, phytoliths are considered to constitute an important system of mechanical defence in angiosperms to reduce feeding pressure by increasing the risk for the animals to damage their teeth. Since opalines are the only substances hard enough to grind and abrade tooth enamel of herbivorous mammals (BAKER et al., 1959), tooth abrasion is one limiting factor for life expectation in herbivorous mammals. The requirement for stiffness and abrasion resistance has led to the development of microstructural reinforcements of molars (RENSBERGER, 1997). Thus, the abrasive effects of phytoliths are already partially compensated for by the dental ultrastructure and enamel prism network.

Further mechanisms of wear control are possibly related to salivary pellicles covering functional dental surfaces. Caries research in humans has revealed that salivary proteins, i.e. proline-rich proteins (PRP's) and mucines, bind to dental enamel. It has been proposed, that mechanical and chemical protection of tooth surfaces may result from such interactions (AMAECHI et al., 1999; DOWD, 1999; LAGERLÔF, 1998; HANNIG, 1997; TABAK, 1995; MEURMAN and FRANK, 1991). Saliva guarantees saturation of the oral cavity with calcium phosphate and thus secures dental integrity (DOWD, 1999). Furthermore, enzymes in saliva serve as cleaning agents of the interdental space and facilitate the removal of bacterial substrates from the oral cavity. (DOWD, 1999; KIVELÄ, 1999).

Compared with humans, both composition of saliva and salivary protein function have been insufficiently investigated in ruminants. While there is a rich literature on cattle as one of our primary sources for meat and milk, our knowledge about the interactions between salivary proteins and dental tissues in these animals is rather incomplete. Initial molecular studies on salivary proteins in ruminants were carried out by JONES et al. (1982) and MCLAREN et al. (1987). Using SDS-PAGE, they discovered 12 distinct protein bands and determined their isoelectric points (IEF) and molecular masses.

The aim of this study was to test whether herbivores with different dietary adaptations such as mixed feeders (e.g. Capra aegagrus f. hircus) or grazers (e.g. Bos primigenius f. taurus) differ in the composition of salivary proteins adhering to dental surfaces. To answer that question [1] bovine and caprine whole saliva protein band patterns were compared and [2] the in vitro interactions of salivary proteins with dental enamel and silicate (glass) were studied.

The knowledge of specific functional adaptations to different diets in the oral milieu of ruminant animals may increase our understanding of the evolution of the morphofunctional complex of the highly specialized digestive system in this extremely successful and diverse group of herbivores. In addition, the structure and binding properties of salivary proteins to dental tissues and food components could elucidate special adaptations to food and habitat resources. 


\section{Materials and methods}

\section{SDS-polyacrylamide gel electrophoresis}

Animals, 5 male and female goats (Capra aegagrus f. hircus), 4 cows and 2 bulls (Bos primigenius $f$. taurus), were obtained from the Research Institute for the Biology of Farm Animals in Dummerstorf. Both bovine and goat permanent lower molars m2 and m3 were examined as dental samples. Lower jaws of slaughtered animals were cut with a water-cooled diamond saw to separate the teeth from their radices. After extraction, molar crowns were cleaned using a sonic bath (Bandelin Sonorex RK 100). Whole saliva was obtained by a non-invasive commonly used method. Animals bit on a cotton pad and afterwards the pads were centrifuged for 10 minutes at $2000 \mathrm{x}$ g to release the saliva. Flow-through was collected in $0.5 \mathrm{ml}$ aliquots. Bovine whole saliva was obtained from 4 cows by natural salivation. Larger food particles were removed by sedimentation. Saliva samples were kept at $-20{ }^{\circ} \mathrm{C}$ until use. Prior to the incubation of dental enamel with saliva, all bovine saliva samples were compared with goat samples using SDS-PAGE.

Tooth samples were prepared by cutting molar crowns into slabs of dimensions in mm (4 length x 4 width x 1 thick) (AMAECHI et al., 1999; HANNIG, 1997). Sample slabs were carefully separated into dental enamel and dentine. After pulverizing the enamel in a mortar, sample powders were sieved using a mesh cascade of $315 \mu \mathrm{m}, 200 \mu \mathrm{m}$, $160 \mu \mathrm{m}, 125 \mu \mathrm{m}$ and $80 \mu \mathrm{m}$. Glass powder (particle size $<80 \mu \mathrm{m}$ ) was used to test the interaction between salivary proteins and silicates. Aliquots of $6 \mathrm{mg}$ of enamel- and glass powder were transferred into $1.5 \mathrm{ml}$ micro tubes. Powder was subsequently rinsed five times with $200 \mu \mathrm{l}$ deionised distilled water each followed by $5 \mathrm{~min}$ centrifugation at $2000 \mathrm{x}$ g. Immediately after a short drying at $37{ }^{\circ} \mathrm{C}, 200 \mu \mathrm{l}$ of whole bovine or goat saliva were added. Negative controls were incubated with $200 \mu \mathrm{l}$ deionised distilled water instead of saliva to show that there were no proteins originating from the dental material itself. The samples were incubated for $4 \mathrm{~h}$ at $37{ }^{\circ} \mathrm{C}$ in a thermo-mixer (Eppendorf thermo-mixer 5436) and then centrifuged for $5 \mathrm{~min}$ at $2000 \mathrm{x}$ g. Supernatants were discarded and powders were washed six times with 200 $\mu \mathrm{l}$ of a $0.9 \% \mathrm{NaCl}$-solution. The first, third and sixth washing supernatants were collected for SDS-PAGE and used as a control for washing-effectiveness, indicating, that no more salivary proteins were washed out from the enamel and glass samples. Powder samples with adherent salivary proteins were added to $10 \mu$ l of sample-buffer (125 mM TRIS, $20 \%$ glycerol, $4 \%$ SDS, $2 \% \beta$-mercaptoethanol, $2 \mu \mathrm{g} / \mathrm{ml}$ bromophenol blue), shortly boiled at $95{ }^{\circ} \mathrm{C}$ and proteins were separated using SDSPAGE on a $5 \%$ stacking gel (125 mM Tris, $0.1 \%$ SDS, pH 6.8) and a $12.5 \%$ resolving gel (375 mM Tris, 0.1 \% SDS, pH 8.8) (JONES et al., 1982; LAEMMLI, 1970; ECKERT and KARTENBECK, 1997). Sigma Standard (SIGMA, Sigma Chemicals Co., St. Louis, USA) was used to determine molecular masses of protein bands. Gels were run at $125 \mathrm{~V}$ for at least $1.5 \mathrm{~h}$ and stained overnight in CoomassieBrilliant-Blue-R250. After destaining (destaining solution: $25 \%$ n-propanol, $10 \%$ glacial acetic acid) gels were incubated for a minimum of $1 \mathrm{~h}$ in $7 \%$ acetone with $4 \%$ glycerol for stabilization. Protein bands were documented by scanning the gel with a standard scanner connected to a personal computer. Apparent molecular masses of salivary proteins were calculated from 3 to 5 replicates according to ECKERT and KARTENBECK (1997). 


\section{MS/MS mass spectrometry}

Bands of enamel binding proteins were cut out of the gel and immediately destained by incubation in $200 \mu \mathrm{l}$ of a $200 \mathrm{mM} \mathrm{NH} \mathrm{HCO}_{3}$-solution for $30 \mathrm{~min}$ at $37^{\circ} \mathrm{C}$. The supernatant was discarded and the gel sample was incubated with $100 \mu \mathrm{l}$ acetonitrile for $15 \mathrm{~min}$. This step was repeated once and thereafter $20 \mu \mathrm{l}$ trypsin solution was added to the gel sample for overnight-digestion at $37^{\circ} \mathrm{C}$. The next day, peptides were extracted using $20 \mu \mathrm{l} \mathrm{Lichrosolv-water} \mathrm{for} 30 \mathrm{~min}$ in a sonic bath at $30^{\circ} \mathrm{C}$.

Peptides were separated by HPLC (high pressure liquid chromatography) using the Ultimate ${ }^{\mathrm{TM}}$ System (LC Packings, Amsterdam, Netherlands). Thereafter, peptides were analyzed in the Q-TOF-mass spectrometer Q-Star Pulsar i (Applied Biosystems, Foster City, CA, USA). Sequence and molecular mass data were used to search the SwissProt data base (ExPASy Proteomics Server) and to identify the corresponding proteins.

\section{Results}

\section{Masses of adherent salivary proteins}

SDS-PAGE of whole saliva revealed six protein bands which occurred in both bovine and goat samples (Fig.1). In total, goat saliva showed 19 bands with molecular weights ranging from 10 to $168 \mathrm{kDa}$. Bovine saliva showed 13 protein bands ranging from 10 to $150 \mathrm{kDa}$. Furthermore, in bovine whole saliva two prominent protein bands (46 and $36 \mathrm{kDa}$ ), which were absent in goat saliva samples, were found (Fig. 1).

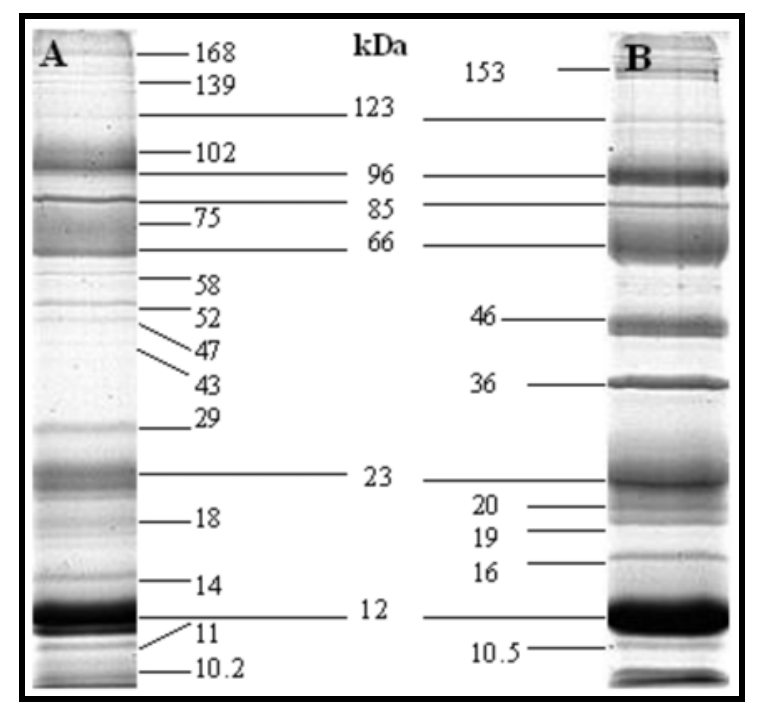

Fig. 1: Salivary proteins of bovine and goat whole saliva separated on $12.5 \%$ SDS-gels: molecular weights are given in $\mathrm{kDa}$. A: goat. B: cattle. Molecular masses of six common protein bands are indicated in the centre (Proteine aus dem Gesamtspeichel von Rind und Ziege wurden auf einem 12,5 \%-igen SDS-Gel aufgetrennt: Molekulargewichte in kDa. A: Ziege. B: Rind. Die Molekulargewichte von sechs gemeinsamen Proteinbanden sind in der Abbildungsmitte angegeben)

First, third and sixth washing-fractions of incubated dental and glass powders showed a decreasing protein-concentration during washing procedure (not shown). SDS-PAGE of enamel- and glass-powder after washing revealed two distinct bovine salivary proteins that bound selectively to bovine enamel and one band selectively binding to glass (Fig. 2 A,B). Weak bands of additional salivary proteins could be detected in the enamel samples. However, only the two most prominent proteins reached the amounts necessary for further analyses. Both proteins also seem to adhere to glass, but at a very low concentration. Negative controls were free of protein bands.

Goat saliva samples only produced very weak signals in stained SDS-gels. However, one protein band was found to be attached to glass-powder (Fig. $2 \mathrm{C}$ ). However, the protein concentration was insufficient for MS/MS mass spectrometry. There was no protein binding detectable neither in enamel samples nor in the negative controls. 


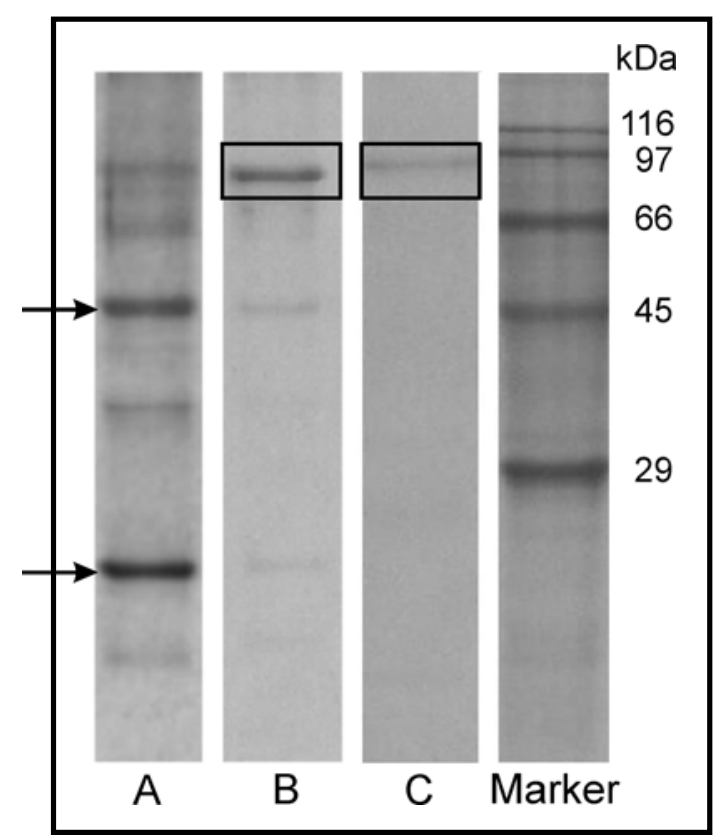

Fig. 2: Separation of adherent proteins on a $12.5 \%$ SDS-gel: Protein bands of bovine whole saliva as eluted from dental enamel powder (A) or glass powder (B) and protein of goat whole saliva eluted from glass powder (C). Molecular masses of Sigma protein standards are given in kDa (Marker). A: Distinct protein bands are marked with arrows and were analysed in MS/MS mass spectrometry. B,C: Glass powder with bound bovine (B) or goat (C) salivary proteins. The band of a possibly silicate-binding protein from bovine and goat saliva is marked (Auftrennung adhärenter Proteine auf einem 12,5 \%-igen SDSGel: Die Proteinbanden aus Rindergesamtspeichel wurden vom Zahnschmelz- (A) oder Glaspulver (B) eluiert, das Protein aus dem Gesamtspeichel der Ziege wurde vom Glaspulver abgelöst (C). Die Molekulargewichte des Sigma Proteinstandards sind in kDa angegeben (Marker). A: Deutliche Proteinbanden sind durch Pfeile hervorgehoben und wurden in der MS/MSMassenspektrometrie analysiert. B,C: Glaspulver mit gebundenen Speichelproteinen von Rind (B) oder Ziege (C). Die Bande eines möglichen Silikat-bindenden Proteins aus Rinder- und Ziegenspeichel ist markiert)

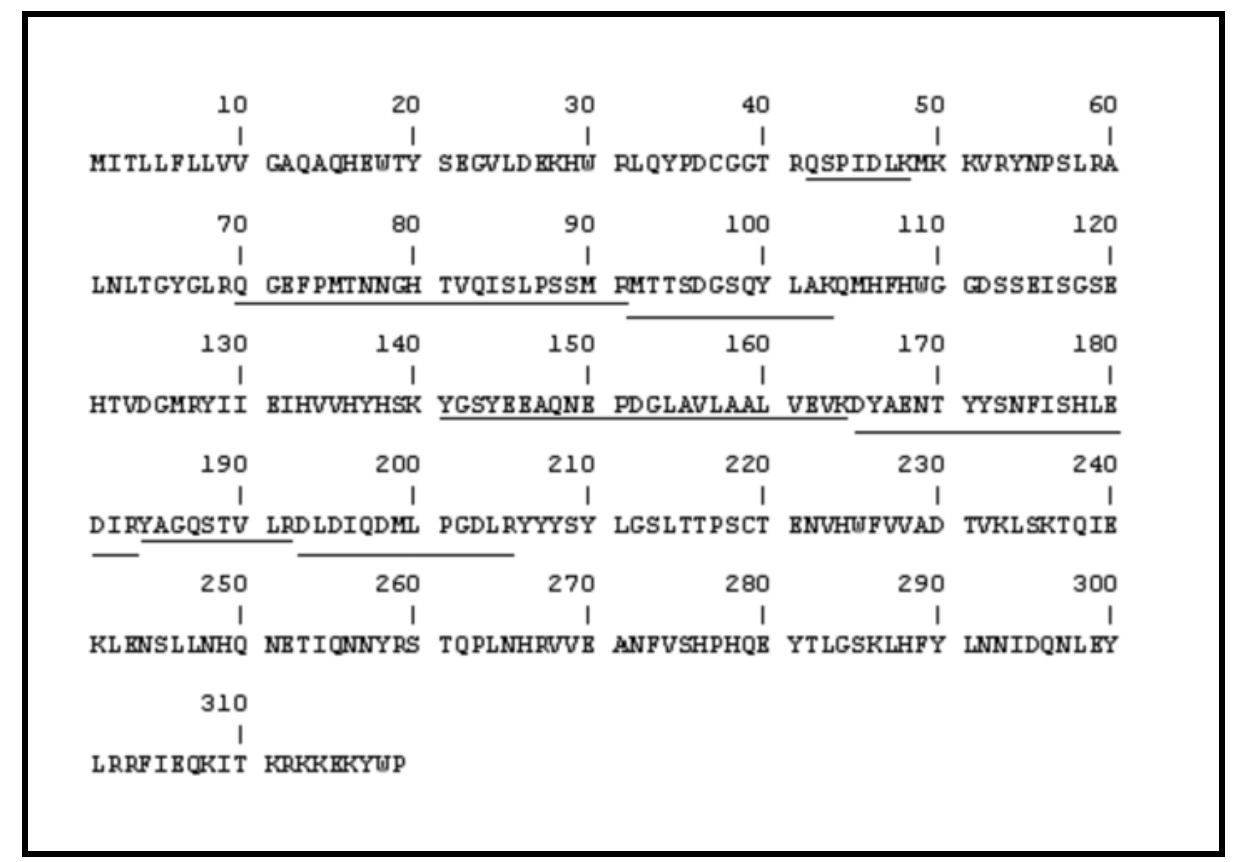

Fig. 3: Amino acid sequence of bovine carbonic anhydrase VI (CA-VI) obtained from the SwissProt database (Accession-no: P18915). Horizontal lines mark the sequence stretches that were covered by peptides analysed by MS/MS mass spectrometry. Sequence covering reached 15 to $33 \%$ within two replicates (Aminosäuresequenz der bovinen Carboanhydrase VI (CA-VI) wie in der SwissProt Datenbank angegeben (Accession-no: P18915). Horizontale Linien markieren diejenigen Sequenzbereiche, die durch die in der MS/MS-Massenspektrometrie untersuchten Peptide abgedeckt werden konnten. Die Sequenzabdeckung betrug 15 bis 33 \% innerhalb zweier Wiederholungen)

\section{Identification of adherent salivary proteins by mass spectrometry}

Two bovine salivary proteins (apparent molecular masses: $46.7 \pm 4 \mathrm{kDa}$ and $11.7 \pm 2$ $\mathrm{kDa}$ ) which adhered to bovine dental enamel were analysed by MS/MS mass spectrometry. The first protein was identified as the bovine salivary carbonic anhydrase VI (CAH6_BOVIN P18915; CA-VI). Two peptides were analysed by sequencing, five by their molecular masses. These peptides covered 15 to $33 \%$ of the CA-VI sequence, that was obtained from the ExPASy-database (ExPASy Proteomics 
Server) (Fig. 3). The coverage was sufficient for an unambiguous identification of the respective protein as a bovine CA-VI-homologue. The molecular mass was calculated as $36.98 \mathrm{kDa}$ according to the data base entry.

The second protein band was identified as the bovine odorant-binding protein (OBP_BOVIN P07435, bOBP). Five peptides were analysed by their sequences, two by the molecular weights. Peptides reached a significant sequence coverage between 32 and $49 \%$ (Fig. 4). The molecular mass of bOBP was calculated as $18.49 \mathrm{kDa}$ according to the data base entry.

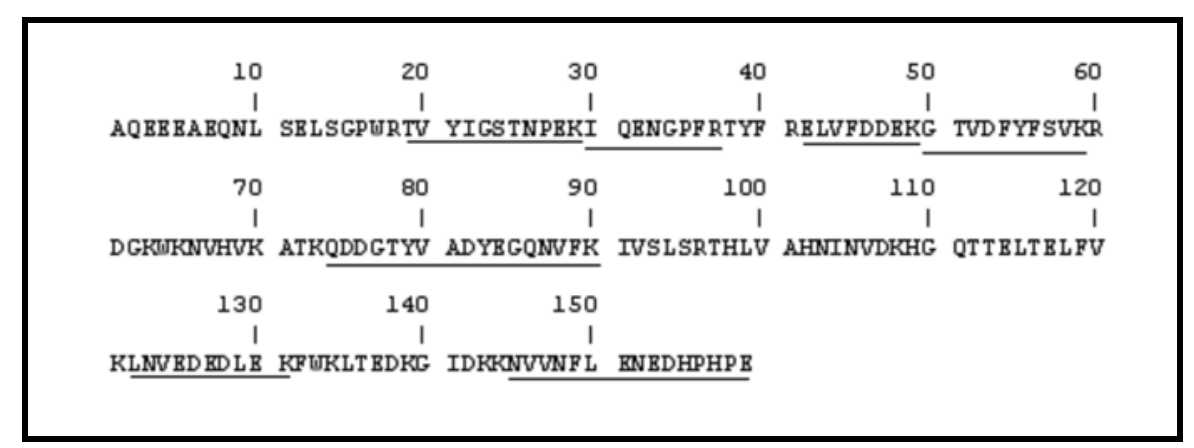

Fig. 4: Amino acid sequence of bovine odorant-binding protein (bOBP) obtained from the SwissProt database (Accession-no: P07435). Horizontal lines mark the sequence stretches that were covered by peptides analysed by MS/MS mass spectrometry. Sequence covering was 32 to $49 \%$ within two replicates (Aminosäuresequenz des bovinen geruchsstoffbindenden Proteins (bOBP), gelistet in der SwissProt Datenbank (Accession-no: P07435). Horizontale Linien markieren die Sequenzteile, die durch die in der MS/MS-Massenspektrometrie untersuchten Peptide abgedeckt wurden. Die Sequenzabdeckung betrug 32 bis $49 \%$ in zwei Wiederholungen)

\section{Discussion}

The two bovid species investigated differ not only in their feeding adaptation (HOFMANN, 1989), but also in the composition of their saliva. The differences may be related to the specific dietary adaptations of the two species. Salivary proteins that bind to dental enamel could have a variety of functions. They may work as precursors for the recruitment of enzymes to dental tissues (JENSEN et al., 1992), as protective agents against mechanical damage (TABAK, 1995) or may act as enzymes removing deleterious metabolites (LAGERLÔF, 1998; HANNIG, 1997).

Adherent to dental enamel we found two distinct proteins. One has been identified as the bovine carbonic anhydrase VI (CA-VI) and the other as the bovine odorant-binding protein (bOBP). In gel electrophoresis, the CA-VI runs at $47 \mathrm{kDa}$, while the true molecular mass is $36.98 \mathrm{kDa}$, according to the data base. This deviation may derive from posttranslational modifications which are not necessarily present in each peptide analysed (JIANG et al., 1996). The CA-VI has been previously described as a component of sheep saliva (FERNLEY et al., 1988, 1989). At present, we know eight isoforms of the carbonic anhydrase, which are expressed in various organisms ranging from bacteria to mammals (KIVEL $\ddot{A}, 1999)$. The bovine CA-VI is expressed in developing bovine parotid glands and can be purified from bovine saliva (ASARI et al., 2000). The CA-VI is the only known carbonic anhydrase that is secreted into body fluids. In the human oral cavity it binds to dental structures and might protect them from corrosive acids (KIVELÄ, 1999). This would make the CA-VI an important factor in pH-regulation, ion transport or electrolyte- and volume homeostasis (JIANG et al., 1996). Furthermore, a surplus of CA-VI in saliva may protect the mucosal 
surface of the oesophagus against acidosis (PARKKILA et al., 1997). A comparable protein has not yet been found in goat saliva.

The odorant-binding protein (OBP) primarily acts as transport-molecule for diverse odorants to their specific receptors in the nasal mucosa (TEGONI et al., 1996). It is supposed, that odorants at apparently low concentrations in the air are concentrated by the OBPs to a level that would be effective in neuronal stimulation (PEVSNER et al., 1986). Bovine OBP has been primarily localized to nasal gland tissues and secretions (PEVSNER et al., 1986). Consistently, in ruminants the oral, nasal and vomeronasal areas can communicate with each other, permanently between mouth and nose, or occasionally between the vomeronasal organ (VNO) and the oral cavity during flehmen, when the incisive duct is opened after stimulation (GUIRAUDIE et al., 2003). Until now, there are no reports of OBPs isolated from bovine dental surfaces. While the teeth provide a large surface area in the mouth, and are among the first oral structures that get into contact with the odorant, specific binding may result in a higher efficiency of odorant and/or pheromonal recognition in the VNO. Additional studies are necessary to test this hypothesis.

Both proteins identified also weakly adhered to glass. This could be caused by diverse interactions with silicate-based surfaces and other salivary precursor proteins that were adherent to the glass powder. Another salivary protein that binds to glass was found in bovine and goat whole saliva. This is supposed to be the first indication for a possibly silicate-binding protein in either species. The protein could protect teeth from mechanical abrasion by phytoliths. However, an identification via MS/MS mass spectrometry is needed in further studies.

Nevertheless, it should be considered, that in vitro adhesion experiments with salivary proteins cannot be representative for all physiological interactions that may occur in vivo (JENSEN et al., 1992). Both the continuous salivary flow and the availability of binding sites are dynamic processes within the oral cavity, which influence the concentrations and the affinity of salivary proteins to potential binding substrates. In order to elucidate possible relationships between salivary proteins, dietary regimes and dietary adaptations in ruminants, further studies are necessary.

\section{Acknowledgements}

The MS/MS analyses were performed by Dr. S. Venz (Biochemistry Research Unit, University of Greifswald) at the Functional Genomics-lab of the university (Prof. Dr. U. Völker). We thank K. Weidemann (Zoological Institute and Museum, University of Greifswald) for his help with the diamond-saw. Bovine and goat tooth specimens and whole saliva were gratefully provided by Dr. G. Klautschek (Research Institute for the Biology of Farm Animals, FBN, Dummerstorf, GERMANY).

\section{References}

AMAECHI, B.T.; HIGHAM, S.M.; EDGAR ,W.M.; MILOSEVIC, A.:

Thickness of acquired salivary pellicle as a determinant of the sites of dental erosion. J. Dent. Res. 78 (1999) 12, 1821-1828

ASARI, M.; MIURA, K.; ICHIHARA, N.; NISHITA, T.; AMASAKI, H.:

Distribution of carbonic anhydrase isozyme VI in the developing bovine parotid gland. Cells Tissues Organs 167 (2000) 1, 18-24

BAKER, G.; JONES, L. H. P.; WARDROP I. D.:

Cause of wear in sheep's teeth. Nature 184 (1959), 1583-1584

DOWD, F.J.:

Saliva and dental caries. Dent. Clin. North. Am. 43 (1999) 4, 579-597

ECKERT, W.A.; KARTENBECK, J.: 
Proteine: Standardmethoden der Molekular- und Zellbiologie. Springer Labormanual. Springer-Verlag (1997)

FERNLEY, R.T.; DARLING, P.; ALDRED, P.; WRIGHT, R.D.; COGHLAN, J.P.:

Tissue and species distribution of the secreted carbonic anhydrase isoenzyme. Biochem. J. 259 (1989) 1, 91-96

FERNLEY, R.T.; WRIGHT, R.D.; COGHLAN, J.P.:

Complete aminoacid sequence of ovine salivary carbonic anhydrase. Biochem. 27 (1988), 2815-2820

GUIRAUDIE, G. ; PAGEAT, P. ; CAIN, A.H. ; MADEC, I. ; NAGNAN-LE MEILLOUR, P.:

Functional characterization of olfactory binding proteins for appeasing compounds and molecular cloning in the vomeronasal organ of pre-pubertal pigs. Chem. Senses 28 (2003), 609-619

HANNIG, M.:

Transmission electron microscopic study of in vitro pellicle formation on dental restorative materials.

Eur. J. Oral. Sci. 105 (5Pt1) (1997), 422-433

HOFMANN, R.R.:

Evolutionary steps of ecophysiological adaptation and diversification of ruminants: a comparative view of their digestive system. Oecologia 78 (1989), 443-457

JENSEN, J.L.; LAMKIN, M.S.; OPPENHEIM, F.G.:

Adsorption of human salivary proteins to hydroxyapatite: a comparison between whole saliva and glandular salivary secretions. J. Dent. Res. 71 (1992) 9, 1569-1576

JIANG, W.; WOITACH, J.T.; GUPTA, D.:

Sequence of bovine anhydrase VI: potential recognition sites for N-acetylgalacttosaminyltransferase. Biochem. J. 318 (1996), 291-296

JONES, W.T.; BROADHURST, R.B.; GURNSEY, M.P.:

Partial characterization of bovine salivary proteins by electrophoretic methods. Biochimica et Biophysica Acta 701 (1982), 382-388

KIVELÄ, J.:

Human salivary carbonic anhydrase isoenzyme VI. Physiology and association with the experience of dental caries, Department of Anatomy and Cell Biology, University of Oulu, Finland, ISBN 951-425140-7, (1999)

LAEMMLI, U.K.:

Cleavage of structural proteins during the assembly of the head of bacteriophage T4. Nature 227 (1970), 680-685

\section{LAGERLOF F.:}

La salive: Une protection naturelle contre la carie. Rev. Belge Med. Dent. 53 (1998) 1, 337-348

MCLAREN R.D., MCINTOSH J.T., HOWE G.W.:

The purification and characterization of bovine salivary proteins by electrophoretic procedures. Electrophoresis 8 (1987), 318-324

MEURMAN, J.H.; FRANK R.M.:

Scanning electron microscopic study of the effect of salivary pellicle on enamel erosion. Caries Res. 25 (1991) 1, 1-6

PARKKILA, S.; PARKKILA, A.K.; LEHTOLA, J.; REINILÄ, A.; SÖDERVIK, H.J.; RANNISTO, M.; RAJANIEMI, H.:

Salivary carbonic anhydrase protects gastroesophageal mucosa from acid injury. Dig. Dis. Sci. 42 (1997), 1013-1019

PEVSNER, J.; SKLAR, P.B.; SNYDER, S.H.:

Odorant-binding protein: Localization to nasal glands and secretions. Proc. Natl. Acad. Sci. USA 83 (1986), 4942-4946

RENSBERGER, J. M.:

Mechanical adaptation in enamel. In: VON KOENIGSWALD, W.; SANDER, M. ED. A. A. BALKEMA. Rotterdam (1997), 237-257

TABAK, L.:

In defense of the oral cavity: structure, biosynthesis, and function of salivary mucins. Ann. Rev. Physiol. 57 (1995), 547-564

TEGONI, M.; RAMONI, R.; BIGNETTI, E.; SPINELLI, S.; CAMBILLAU, C.:

dDomain swapping creates a third putative combining site in bovine odorant binding protein dimmer. Nat. Struct. Biol. 3 (1996) 10, 863-867

Received: 2006-04-20

Accepted: 2006-06-26

Corresponding Author

MARCUS MAU, present address: Research Institute for the Biology of Farm Animals,

Muscle Biology \& Growth Research Unit, Wilhelm-Stahl-Allee 2,

18196 DUMMERSTORF, GERMANY

E-Mail: mau@fbn-dummerstorf.de 